Maciej Rak •

Uniwersytet Jagielloński, Kraków

maciej.rak@uj.edu.pl

\title{
OD REDAKTORA NACZELNEGO
}

W niniejszym numerze „LingVariów” publikujemy m.in. tekst Bogusława Dunaja o zmarłym 24 maja 2021 r. Profesorze Aleksandrze Zajdzie. W tym miejscu chciałbym nieco dokładniej przypomnieć Jego związki z naszym czasopismem.

Zanim zmieniły się procedury wydawnicze, co nastąpiło mniej więcej 12 lat temu, redakcja „LV” powoływała Aleksandra Zajdę na recenzenta artykułów historycznojęzykowych (dziś - jak wiadomo - recenzenci mają być tylko zewnętrzni). Nigdy nie odmawiał tej współpracy, a recenzje Jego autorstwa - podobnie jak całe Jego życie i działalność naukowa - cechowały się uczciwością, obiektywizmem i dokładnością. Aleksander Zajda był autorem aż 11 artykułów opublikowanych na łamach „LV”:

1) Staropolskie nazwy sporów sądowych $i$ procesów, oparte na prasł. * per-ti $i$ ich historia w jezzyku polskim („LV” 2006, nr 1, s. 117-124);

2) Staropolskie nazwy osób występujących przed sądem, oparte na prast. * per-ti i ich historia w języku polskim („LV” 2006, nr 2, s. 37-46);

3) O geografii nazw staropolskich powinności feudalnych, danin i opłat i jej uwarunkowaniach („LV” 2007, $\mathrm{nr} 1$ (3), s. 51-63);

4) Historia pola wyrazowego ACCUSATIO 'skarga', 'oskarżenie' w języku polskim („LV” 2008, $\mathrm{nr} 1$ (5), s. 109-130);

5) Historia języka polskiego dzisiaj. Możliwości, zadania i postulaty w zakresie badań nad historia słownictwa polskiego („LV” 2010, $\mathrm{nr} 2$ (10), s. 75-101);

6) Rozważań nad Słowami prawnymi w rzeczy sobie podobnymi Bartłomieja Groickiego ciag dalszy („LV” 2011, nr 2 (12), s. 111-124);

7) Trzecie rozważania nad Słowami prawnymi w rzeczy sobie podobnymi Bartłomieja Groickiego („LV” 2012, nr 2 (14), s. 89-109); 
8) Czwarte rozważania nad Słowami prawnymi w rzeczy sobie podobnymi Bartłomieja Groickiego („LV” 2013, nr 1 (15), s. 89-110);

9) Po raz piąty wychodzac od Słów prawnych w rzeczy sobie podobnych Bartłomieja Groickiego (1567) („LV” 2013, $\mathrm{nr} 2$ (16), s. 215-229);

10) Nieliterackie źródła do dziejów słownictwa polskiego (do XVIII w.). Cz. I („LV” 2016, nr 1 (21), s. 123-138);

11) Nieliterackie źródła do dziejów słownictwa polskiego (do XVIII w.). Cz. II („LV” 2016, $\mathrm{nr} 2$ (22), s. 165-181).

Zawsze też Profesor z życzliwością traktował zarówno czasopismo, jak i redakcję (czy w ogóle był dla kogokolwiek nieżyczliwy? Wątpię). Gdy był już na emeryturze, często spotykałem Go w czytelni Wydziału Polonistyki UJ albo w jej okolicach. Z żarliwością i przejęciem mówił mi o swoich rozpoczętych pracach, tak wiele miał jeszcze planów i pomysłów... 